\title{
科学工作者要爲全部实現我國 第一個五年計劃而䔰鬥
}

社論

以唒会主義工業化作䉆中心的我國梫辳國民

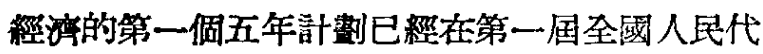
表大会第二次会議上討諭通过了。多年來，中國 人民, 包括全國的科学工作者迫切朌望着自己祖 國的工業化和富强，这倜在鹤中国不汀能实現的 頋望，在中國共㡾党和毛主庥領導的人民革命勝 利後，經过個五年計劃就將得刢实現。第一值 五年計劃給全國人民指出了篇实現这眖硕望而閏 争的具体途徑，它是全國六万万人的当前的共同 的行動綱領。

第一個五年計劃的实現將便我們國家的經橓 面貌与社会面貌開始発生根本的變化。五年內,

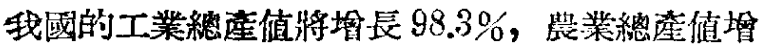
長 $23.3 \%$ ，現代工業在工業農 業繼值帙比 重，将由 $26.7 \%$ 上昇到 $36 \%$ 。到 1957 年，全國 患戶總數中将有三分之一參加擘業生產合作佂， 全國私管工商業都將基本上被納入国家資本主義 的軌道。所有这一切都標誌着五年裏我们祖國將 在实現过渡時期總任務的道路上大大地堂進一

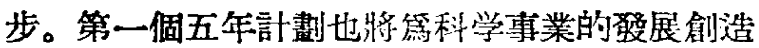
前所未有的有利條件，它问科学工作者提出的莊 照任務更給予全國科学工作者以巨大的攱舞。

在第一個五年計劃裹，我們脟大力灌行以苏

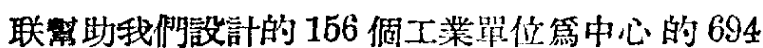
個限额以上的工業單位的建就工作。五年赛，鉄 的年產能力將垥加 280 万顿，墭的年举能力將燴 加 253 万顿, 很多过去所不能製造的工業設備都 將能够開始大規模地製造。五年裏，我們还將開 始進行黃河的根浩和綜合開發工作，開始建設發 電量 100 万千瓦的巨大的三門峽水利、水力樞紐 工程。像这樣規模宏大的工業建設是不能離閉現 代的科学技術的全力支援的。在工業和運輸業的
基本建設中，必須進行全國各地區地筫磕库資源 的誥查趿探和自然佟件的調查的究工作，必須稨 了正磪地規劃、設汁与施工而進行閣於基标建設

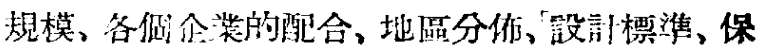

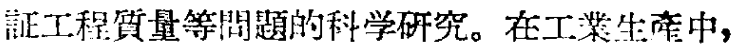
第了完成第一個五年部劃所提出的提初質量、加

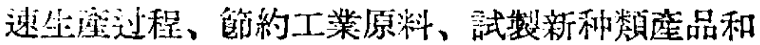
提高企業的管理工作水本等重大任務，也同栐需 要進行大量的科学技眞工作。科学工作渚有责任 以自己的工作來不斷地提供和推行先進的科学技 術成就，保证工棠建設和工業生萑在更高的科学 技術水平上更迅速地進行。關於从科学技石方面

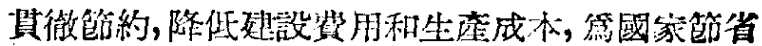
和積照资金，科学工作者也负行電大責任。

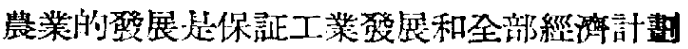

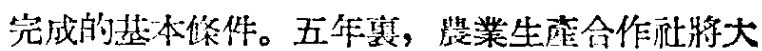

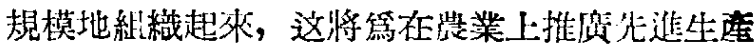
技術和提高產量提供出很有利的佟件。我國墢展 费業最重要的任務就是粮食和工業原料的增產。 科学工作者必須以極大的努力來解决这方面的科 学問題。第一個五年計劃所提出的各項具体曙库 措施, 例如利脂自然資源, 撗大耕地面皘, 勘察

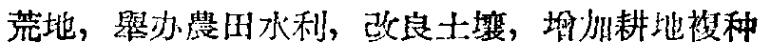
指數，加强水土保持工作，增加稻米、王米、薯

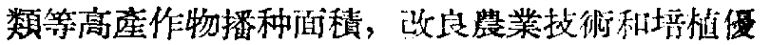
良种類，預防自然災害，改良粮食（特別是落類） 的儲藏和加工等方面, 都有一系列重姴的科学問 題等待着研究解决。科学工作者应該十分珍視數

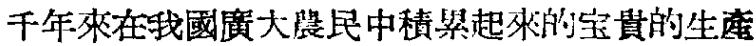
桱驗，必須普於学留亚在現代科学理諭的指導下

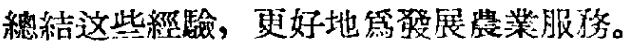

目前，世界巳開始進入原子能的洔代。在偉 
大苏联的無私的直接繁助下，五年內我國牌開始 和平利用原子能的起設，使它䍃國傢建設和人民

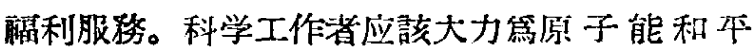
利用证篇利用原子能來發隻各門科学的工作而努 カ。

五年裏，烝保証人民物咓生活和文化生活水 平的相应提高，在保健、衛生、文学、埶術等方 面的科学研究也必須大大加强。

科学工作者应該把支援國防建設看作是自己 的光策任務, 國防現代化需要先進的科学成就与 不断的科学研究工作的支嗳, 我們每一個科学工. 作者都深深地了解莘固的國防是我國和平建設和

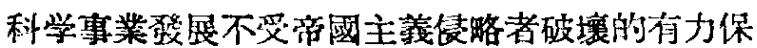
觯。

在过渡特期，我們國家將逐步消减舦制制 度，建立社会主義社会。这是社会主義同資本主

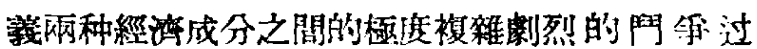
程，是一個日豀廣泛深刻的尖㷺的階級鬥学过程。 在过渡時期階粐鬥等的实踐中所提出來的各种 科学問題, 同樣地等待着科学工作者予以研究解 决。第了保証酰会主義的利，科学工作者必須 在馬克思列蜜主義思想的指導下深入地研究过渡 時期的凯業手工業改造問題、私營工商業改造問 題, 研究过渡時期社会㡎展的規律, 總結階級閏 争的經簽; 必須積極地參加到批判資產階級唯心 主議思想、豈傳唯物主義思想的鬥爭中去，並在 网筆中努力提高自己的思想水本。

在第一個五年訫劃期間，科学工作者还必須 第第二個五年計劃和第三個五年計劃進行許多淮 脌工作，第國家的長遠計劃提供必要的科学根摸 和科学技術人才，在这方面的工作任務也是很繁 重的。

國落院李富春副總理關於發展國民經浧的第

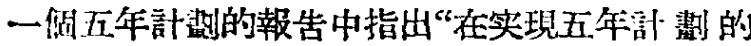
琵绝中，科学、技街工作者担負着重大的責任。 社会主義建設事業迫切要求科学和技術，沒有科 学和技術就不能建設社会主義。因此，不論在那 一部門工作的科学㸴究人县和工程技術人員, 都 应該不斷地捉高政治思想水平和科学技石水本，

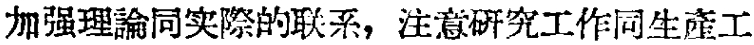
作的联系，在社会主義建設事業中立分谼揮科学
和技術的们用，把公個人的智恝貢献給國家和人 民。”圶國科学工作者必須深刻須会和谓徽这一指 示。怒力学晳馬克思列蜜主義和苏联的先進科学

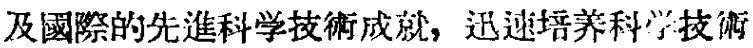
幹部, 大力㺕展國家迫切需要的学科, 在科学 院、高等学校、各産業部門、各重留的工做、碳

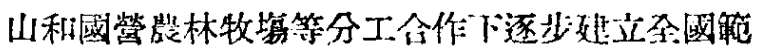

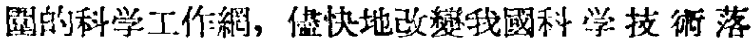
後、学科不夻、力量薄弱、地品分作不合理的狀

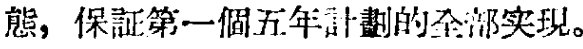

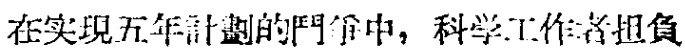

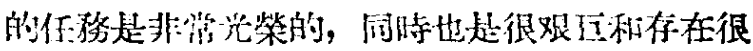

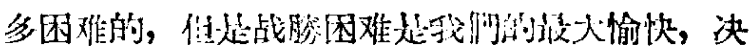

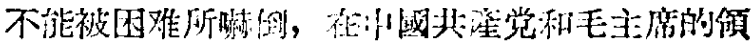

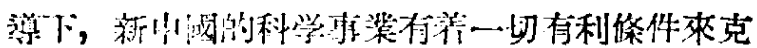

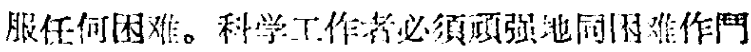

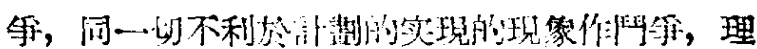
論必須联系实绦，科学湖究工作必须服从國家建

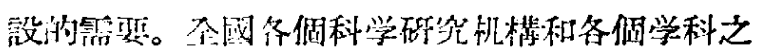

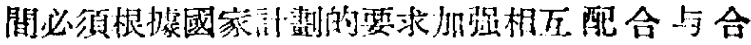
作。因此，各科学机梅和全体科学工作者加强計

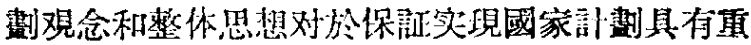

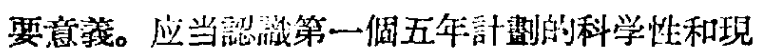
实性，它是我國社会發展的客覌規律的具体 反

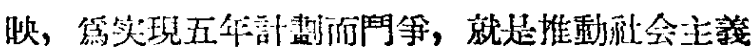

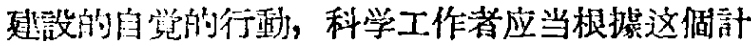

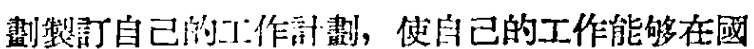
民經沙建没中發挥最大的作用。有人認䍃科学工

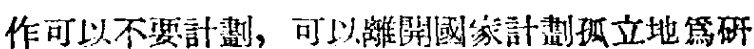

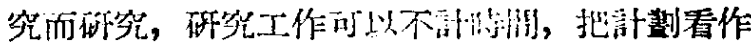

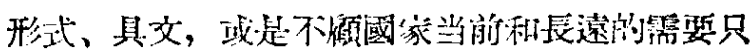

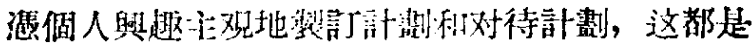

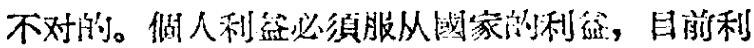

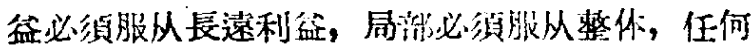

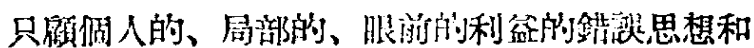
作法都定極端有害的，必須加以批判和紏正。

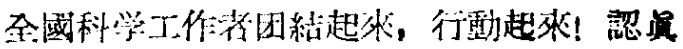
地、樑入地学柏和研究我淢的第一㑑五年計劃!

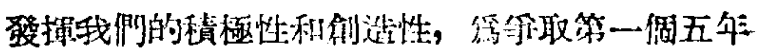
計割早日全部实現而貝擜出自己最大的力量。 